\title{
Left Ventricular Hypertrophy dan Fungsi Ginjal pada Penderita Hipertensi
}

\author{
Heru Sulastomo ${ }^{1}$, Fadlan Akhyar Fauzi ${ }^{2}$, Ratna Kusumawati ${ }^{3}$ \\ 1.Departemen Kardiologi dan Kedokteran Vaskular, Fakultas Kedokteran, Universitas Sebelas \\ Maret \\ 2. Fakultas Kedokteran, Universitas Sebelas Maret \\ 3. Departemen Fisiologi, Fakultas Kedokteran, Universitas Sebelas Maret
}

Korespondensi : herusulastomo@gmail.com

\begin{abstract}
ABSTRAK
Pendahuluan: Hipertensi kronik dapat menimbulkan komplikasi pada organ jantung berupa left ventricular hypertrophy $(\mathrm{LVH})$. Keadaan $\mathrm{LVH}$ dapat memicu terjadinya vasokonstriksi arteri renal, penurunan perfusi darah ke glomerulus dan perubahan koefisien filtrasi glomerulus Penelitian ini bertujuan membandingkan fungsi ginjal antara pasien hipertensi dengan LVH dengan pasien hipertensi tanpa LVH.

Metode: Desain penelitian ini merupakan studi case control yang dilakukan di RSUD Dr. Moewardi Surakarta. Seluruh subjek penelitian merupakan pasien yang telahmenderita hipertensi lebih dari 5 tahun. Penentuan diagnosis LVH berdasar hasil elektrokardiografi (EKG). Fungsi ginjal dinilai berdasar kadar ureum, kreatinin dan asam urat serum.

Hasil: Subjek penelitian terdiri dari 26 pasien hipertensi tanpa LVH dan 13 pasien hipertensi dengan LVH. Kadar ureum serum pada subjek hipertensi dengan LVH lebih tinggi dibandingkan subjek tanpa LVH $(24,92 \pm 7,99$ Vs $32,33 \pm 9,91, p=0,004)$. Kadar asam urat pada subjek hipertensi dengan LVH lebih tinggi daripada subjek tanpa LVH $(5,26 \pm 1,15$ Vs $6,98 \pm 1,83, p=0,029)$. Sedangkan kadar kreatinin serum tidak berbeda bermakna antara kedua kelompok subjek.

Kesimpulan: Kadar ureum dan asam urat serum pada subjek hipertensi dengan LVH lebih tinggi daripada subjek tanpa LVH. Tidak terdapat perbedaan kadar kreatinin antara subjek hipertensi tanpa LVH dan dengan LVH
\end{abstract}

Kata Kunci: left ventricular hypertrophy, ureum serum, asam urat serum, kadar kreatinin serum

\begin{abstract}
Introduction: Chronic hypertension can cause complication such as left ventricular hypertrophy $(L V H)$. LVH can lead renal artery vasoconstriction, impaire blood perfusion to glomerulus and change glomerulus filtration coeficient. The aim of this study was to compare kidney function between hypertensive patient with LVH and without LVH

Methods: This was a case control study that conducted at Dr. Moewardi General Hospital Surakarta. All subjects has been diagnosed as hypertension more than 5 years. The diagnosis of LVH was based on electrocardiography (ECG) result. Kidney function was assessed based on serum ureum, creatinin, and uric acid levels.

Results: The subject of this study was 26 hypertension patients with LVH and 13 hypertension patients without LVH. Serum ureum level in patients with LVH was higher than hypertension patients without $\mathrm{LVH}(24.92 \pm 7.99 \mathrm{Vs} 32.33 \pm 9.91, p=0.004)$. Serum uric acid level in hypertension patients with LVH was higher compare to hypertension patients without $L V H$ as well $(5.26 \pm 1.15$ Vs $6.98 \pm 1.83$, $p=0.029)$. Whereas serum creatinine levels were not significantly different between two groups of subjects.
\end{abstract}


Conclusion: : Serum ureum and uric acid levels in hypertensive subjects with LVH are higher than subjects without $L V H$. There is no difference between serum creatinin level in hypertensive subject with $L V H$ and without $L V H$.

Keywords: left ventricular hypertrophy, serum ureum, serum uric acid, serum creatinine

\section{PENDAHULUAN}

Hipertensi merupakan salah satu penyebab kematian yang cukup tinggi di dunia. Data epidemiologi memperlihatkan hipertensi menyumbang sekitar $12,8 \%$ dari total jumlah kematian dunia ${ }^{1}$. Data Riset Kesehatan Dasar menunjukkan bahwa angka kejadian hipertensi di Indonesia dilaporkan mengalami peningkatan menjadi $34,1 \%$ di tahun 2018 dibandingkan pada tahun 2013 sebesar $25,8 \%{ }^{2}$.

Kematian akibat hipertensi terjadi karena kerusakan organ target. Peningkatan tekanan darah dalam waktu yang lama menyebabkan kerusakan struktur dan fungsi berbagai organ $^{3}$. Organ vital yang sering mengalami kerusakan akibat hipertensi adalah jantung, otak, mata dan ginjal ${ }^{4,5}$.

Hipertensi kronik berkaitan erat dengan terjadinya gangguan dan penurunan fungsi ginjal. Kerusakan pada ginjal terjadi karena peningkatan tekanan glomerulus, peningkatan glomerulus filtration rate (GFR) dan kerusakan nefron ${ }^{6,7}$. Efek kerusakan ginjal akibat hipertensi dapat terjadi asimptomatik sampai dengan kerusakan ginjal terminal ${ }^{5}$.

Left Ventricular Hypertrophy (LVH) merupakan komplikasi hipertensi kronik yang terjadi pada organ jantung 5 . Pada keadaan hipertensi akan terjadi peningkatan beban hemodinamik di sirkulasi ${ }^{8}$. Untuk mengatasi hal tersebut, jantung melakukan kompensasi dengan cara meningkatkan kontraktilitas otot jantung dan menambah massa otot. Selain itu, tubuh juga melakukan kompensasi lain melalui mekanisme stimulasi sistem saraf simpatis dan sistem renin-angiotensinaldosteron (RAAS) yang keduanya ikut memicu terjadinya hipertrofi otot jantung ${ }^{9}$.
Keadaan LVH yang berkelanjutan akan menyebabkan disfungsi diastolik ventrikel kiri. Hal ini akan memicu vasokonstriksi arteri renal, penurunan perfusi darah ke glomerulus dan perubahan koefisien filtrasi glomerulus ${ }^{6}$. Parameter yang rutin dipakai di klinis untuk menilai fungsi ginjal adalah kadar ureum, kreatinin dan asam urat 10. Penelitian ini bertujuan membandingkan kadar ureum, kreatinin dan asam urat serum antara pasien hipertensi dengan LVH dan pasien hipertensi tanpa LVH.

\section{METODE}

Penelitian ini merupakan studi case control yang dilakukan di RSUD Dr. Moewardi Surakarta. Subjek penelitian ini adalah pasien yang telah menderita hipertensi lebih dari 5 tahun. Diagnosis hipertensi didapatkan dari rekam medik dan telah dikonfirmasi oleh dokter ahli jantung. Pasien yang memiliki riwayat hemodialisa, penyakit diabetes mellitus, infeksi saluran kemih, batu saluran kemih, keganasan, sindrom metabolik, hipertiroid dan infeksi berat diekslusi dari penelitian ini.

Pemeriksaan tekanan darah pada subjek penelitian dilakukan di lengan kanan atas menggunakan spygnomanometer air raksa. Penentuan LVH didapatkan dari penilaian dokter ahli jantung berdasarkan hasil pemeriksaan elektrokardiografi (EKG). Hasil pemeriksaan laboratorium kadar ureum, kreatinin dan asam urat serum digunakan untuk menilai fungsi ginjal. Nilai rujukan normal yang digunakan di RSUD Dr. Moewardi Surakarta untuk kadar kreatinin serum $(0,9-1.3 \mathrm{mg} / \mathrm{dl})$, kadar ureum serum $(<50 \mathrm{mg} / \mathrm{dl})$ dan kadar asam urat serum $(2,4-$ 
$6,1 \mathrm{mg} / \mathrm{dl})$ ). Data yang diperoleh dianalisis menggunakan uji $\mathrm{T}$ tidak berpasangan.

Protokol yang dilakukan pada penelitian ini telah mendapat persetujuan Komite Etik RSUD Dr. Moewardi Surakarta/ Fakultas Kedokteran Universitas Sebelas Maret Surakarta. Setiap subjek penelitian telah mengisi informed consent.

\section{HASIL}

\section{Karakteristik}

Total pasien yang memenuhi kriteria inklusi sebanyak 39 pasien yang terdiri dari 26 pasien hipertensi tanpa LVH dan 13 pasien hipertensi dengan LVH. Rata-rata usia pada kelompok hipertensi dengan LVH menunjukkan usia yang lebih muda dibanding kelompok hipertensi tanpa LVH. Rata-rata Indeks Masa Tubuh (IMT) antara kedua kelompok memperlihatkan besaran yang serupa (Tabel 1).

Tabel 1. Karakteristik subjek berdasar umur, jenis kelamin dan IMT

\begin{tabular}{ccc}
\hline & $\begin{array}{c}\text { Hipertensi } \\
\text { Tanpa LVH }\end{array}$ & $\begin{array}{c}\text { Hipertensi } \\
\text { dengan LVH }\end{array}$ \\
\hline Total subjek & 26 & 13 \\
Usia (Tahun) & $61,73 \pm 9,53$ & $56,22 \pm 12,62$ \\
Laki-laki & $10(38,46 \%)$ & $7(53,85 \%)$ \\
Perempuan & $16(61,54 \%)$ & $6(46,15 \%)$ \\
IMT $\left(\mathrm{kg} / \mathrm{m}^{2}\right)$ & $25,40 \pm 4,57$ & $25,52 \pm 2,40$ \\
\hline
\end{tabular}

Hasil pemeriksaan kadar ureum, kreatinin dan asam urat serum pada kedua kelompok menunjukkan hasil yang lebih tinggi pada kelompok hipertensi dengan LVH. Tabel 2 menunjukkan hasil analisis statistik ada perbedaan yang bermakna kadar ureum dan asam urat serum antara kelompok hipertensi dengan LVH dan hipertensi tanpa LVH $(p=0,004)$. Sedangkan untuk kadar kreatinin serum tidak berbeda bermakna antara kedua kelompok tersebut $(p=0.029)$.

\section{Fungsi Ginjal}

Tabel 2. Data hasil pemeriksaan kadar ureum, kreatinin dan asam urat serum

\begin{tabular}{lccc}
\hline & $\begin{array}{c}\text { Hipertensi } \\
\text { Tanpa LVH } \\
(\mathrm{mg} / \mathrm{dl})\end{array}$ & $\begin{array}{c}\text { Hipertensi } \\
\text { dengan LVH } \\
(\mathrm{mg} / \mathrm{dl})\end{array}$ & $\mathrm{p}$ \\
\hline Ureum & $24,92 \pm 7,99$ & $32,33 \pm 9,91$ & 0,004 \\
Kreatinin & $0,77 \pm 0,18$ & $1,77 \pm 2,16$ & 0,136 \\
$\begin{array}{l}\text { Asam } \\
\text { urat }\end{array}$ & $5,26 \pm 1,15$ & $6,98 \pm 1,83$ & 0,029 \\
& & & \\
\hline
\end{tabular}

\section{PEMBAHASAN}

Kejadian hipertensi sangat berkaitan erat dengan faktor usia. Prevalensi peningkatan tekanan darah sistolik terbesar pada usia 50 tahun atau lebih ${ }^{11}$. Data ini sesuai dengan hasil penelitian ini yang menunjukkan usia pada kelompok pasien hipertensi tanpa LVH maupun hipertensi dengan LVH di atas 50 tahun. Seseorang yang tidak menderita hipertensi sampai dengan usia 55 tahun akan memiliki risiko menderita hipertensi pada usia selanjutnya $^{12}$

Hasil penelitian ini menunjukkan pada kelompok hipertensi tanpa LVH jumlah pasien perempuan lebih banyak dibandingkan laki-laki. Sedangkan pada kelompok hipertensi dengan LVH, antara laki-laki dengan perempuan memiliki jumlah yang hampir sama. Jumlah pasien hipertensi perempuan lebih banyak jumlahnya kemungkinan disebabkan rata-rata usia pasien di atas 50 tahun yang telah memasuki masa menopause. Rata-rata usia perempuan di Asia memasuki masa menopause berkisar usia 42,1 sampai 49,5 tahun $^{13}$. Perempuan yang telah menopause memiliki risiko lebih tinggi menderita hipertensi karena produksi hormon estrogen telah menurun. Hormon estrogen memiliki fungsi proteksi terhadap disfungsi 
endotel sehingga mencegah terjadinya hipertensi pada perempuan ${ }^{14}$.

IMT merupakan salah satu faktor risiko penyakit kardiovaskular. Seseorang yang overweight memiliki risiko 2 kali lebih mudah terkena hipertensi dan penderita obesitas memiliki risiko 3 kali untuk terkena hipertensi ${ }^{15}$. Hasil penelitian ini konsisten dengan teori yang telah ada di mana baik pada kelompok hipertensi tanpa LVH maupun hipertensi dengan LVH memiliki rata-rata IMT lebih dari 25. Penelitian yang dilakukan Suman Dua et al membuktikan bahwa IMT memiliki korelasi positif dengan peningkatan tekanan darah sistolik dan diastolik ${ }^{16}$.

Penemuan menarik dari penelitian ini adalah meskipun kreatinin pada kedua kelompok tidak berbeda bermakna, akan tetapi rata-rata kadar kreatinin pada kelompok hipertensi dengan LVH menunjukkan nilai di atas normal. Sedangkan untuk kadar ureum dan asam urat di kedua kelompok walaupun menunjukkan perbedaan yang bermakna akan tetapi kadarnya masih dalam batas nilai normal. Peningkatan kadar ureum dan kreatinin serum merupakan parameter awal dugaan terjadinya gangguan fungsi di ginjal ${ }^{17}$. Kreatinin merupakan indikator fungsi ginjal yang lebih spesifik dibandingkan ureum. Kreatinin dihasilkan secara endogen di dalam tubuh dan difiltrasi di glomerolus. Adanya penurunan GFR akan menyebabkan peningkatan konsentrasi kreatinin plasma $^{18}$. Faktor lain yang mempengaruhi kadar kreatinin serum di antaranya faktor diit, aktivitas fisik dan perombakan masa otot ${ }^{17}$. Selain akibat penurunan fungsi ginjal, peningkatan kadar ureum serum dapat dipengaruhi diit tinggi protein dan keadaan dehidrasi ${ }^{18}$.

Asam urat merupakan produk metabolisme purin dan diekskresikan melalui ginjal. Adanya kerusakan endotel dan penipisan arteriole afferent ginjal berhubungan dengan peningkatan kadar asam urat di dalam serum ${ }^{19}$. Studi yang telah ada memperlihatkan bahwa pada populasi hipertensi yang mengalami peningkatan kadar asam urat memiliki risiko progresivitas gangguan ginjal $^{20}$. Dengan demikian kadar asam urat serum merupakan salah satu parameter yang digunakan untuk menilai progresivitas kerusakan di ginjal ${ }^{10}$.

Peningkatan ketiga parameter fungsi ginjal pada penelitian ini memperlihatkan hipertensi dengan LVH mempunya keterkaitan dengan penurunan fungsi ginjal. Hal ini konsisten dengan penelitian sebelumnya bahwa LVH pada pasien hipertensi menjadi prediktor progresivitas pada pasien yang mengalami Chronic Kidney Disease $(\mathrm{CKD})^{21}$. Studi yang dilakukan pada pasien hipertensi berusia lebih dari 60 tahun menunjukkan adanya penurunan GFR yang lebih cepat pada subjek dengan $\mathrm{LVH}^{6}$.

Penelitian ini memiliki beberapa keterbatasan. Pertama, jumlah pasien hipertensi dengan LVH lebih sedikit dibandingkan pasien hipertensi tanpa LVH dengan pemeriksaan kadar ureum, kreatinin dan asam urat yang dilakukan satu kali. Kedua, penentuan LVH dilakukan menggunakan EKG yang bukan merupakan standar baku untuk menilai LVH. Ketiga, data penggunaan obat-obatan tidak ikut dianalisis. Untuk penelitian selanjutnya perlu dilakukan dengan melibatkan subjek yang lebih besar, penentuan LVH menggunakan standar baku ekokardiografi dan analisis obatobatan yang digunakan oleh subjek penelitian.

\section{KESIMPULAN}

Penemuan pada penelitian ini menunjukkan kadar ureum dan asam urat serum pada subjek hipertensi dengan $\mathrm{LVH}$ lebih tinggi daripada subjek hipertensi tanpa LVH. Ditemukan juga bahwa kadar kreatinin serum pada subjek hipertensi dengan LVH cenderung lebih tinggi walaupun tidak berbeda signifikan dibandingkan subjek hipertensi tanpa LVH. 


\section{DAFTAR PUSTAKA}

1. World Health Oganization (WHO). A global brief on Hypertension : Silent killer, global public health crisis. Jenewa: WHO; 2013. http://www.who.int/topics/hypertension/en / diakses April 2017.

2. Kementerian Kesehatan Republik Indonesia (Kemenkes RI). Riset Kesehatan Dasar (Riskesdas) 2018. Jakarta: Kemenkes RI; 2018.

3. Nadar SK, Tayebjee MH, Messerli F, Lip GYH. Target organ damage in hypertension: pathophysiology and implications for drug therapy. Curr Pharm Des 2006; 12(13):1581-1592.

4. Ramli A, Ahmad NS, Paraidathathu T. Medicationadherence among hypertensive patients of primary health clinics in Malaysia. Patient Prefer and Adherence 2012; 6:613-622.

5. Abegaz TM, Tefera YG, Abebe TB. Target organ damage and long term effect of nonadherence to clinical practice guidelines in patients with hypertension: a retrospective cohort study. Int J Hypertens 2017; 2017:1-8.

6. Shi HT, Wang XJ, Li J, Song GF, Huang ZY, Guo XY, dkk. Association of Left Ventricular Hypertrophy with a faster rate of renal function decline in elderly patients with non-end-stage renal disease. J Am Heart Assoc 2015; 4(11): 1-7.

7. Mensah GA. Hypertension and target organ damage: Don't believe everything you think!. Ethn Dis 2016; 26(3): 275-78.

8. Sudoyo AW, Alwi I, Setiati S, Setiyohadi B, Simadibrata M (2009). Buku Ajar Ilmu Penyakit Dalam Jilid 1, edisi 5. Jakarta: Interna Publishing.

9. Kahan T, Bergfelt L. Left ventricular hypertrophy in hypertension: Its Arrhythmogenic potential. Heart 2005; 91: 250-256.
10.Gowda S, Desai PB, Kulkarni SS, Hull VV, Math AAK, Vernekar SN. Markers of renal function test. North Am J Med Sci 2010; 2:170-173.

11. Pinto E. Blood pressure and ageing. Postgrad Med J 2007; 83:109-114

12. Lionakis N, Mendrinos D, Sanidas E, Favatas G, Georgopoulou M. Hypertension in the elderly. World $\mathrm{J}$ Cardiol 2012; 4(5) 135-147.

13. Palacios S, Henderson VW, Siseles N, Tan D, Villaseca P. Age of menopause and impact of climacteric symptoms by geographical region. Climacteric, 13(5) : 419-428.

14. Ashraf MS, Vongpatanasin W. Estrogen and hypertension. Curr Hypertens Rep 2006;8(5):368-376.

15. Li W, Wang D, Wu C, Shi O, Zhou Y, $\mathrm{Lu} \mathrm{Z}$. The effect of boody mass index and physical activity on hypertension among Chinese middle-aged and older population. Sci Rep 2018;7: 1-7.

16. Dua S, Bhuker M, Sharma P, Dhall M, Kapoor S. Body mass index relates to blood pressure amomg adults. N Am J Med Sci 2014;6(2): 89-95.

17. Banfi G, Del F. Serum creatinine values in elite athletes competing in 8 different sports: comparison with sedentary people. Clin Chem 2006; 52: 330-331.

18. Salazar J H. Overview of Urea and creatinin. Lab medicine 2014; 45(1): e19e20.

19. Giordano C, Karasik O, King-Morris K, Asmar A. Uric acid as a marker of kidney disease: review of current literature. Dis Markers 2015: 1-7.

20. Johnson RJ, Segal MS, Srinivas T, Ejaz $\mathrm{A}, \mathrm{Mu} \mathrm{W}$, Roncal C, dkk. Essential hypertension, progressive renal disease, and uric acid: a pathogenetic link? J Am Soc Nephrol 2005; 16(7): 1909-1919.

21. Ravera M, Noberasco G, Signori A, Re M, Filippi A, Cannavo R, dkk. Leftventricular hypertrophy and renal 
Sulastomo et.al., Left Ventricular Hypertrophy dan Fungsi Ginjal pada Penderita Hipertensi

outcome in hypertensive patients in

primary-care. Am J Hypertens.

2013;26(5): 700-707. 